\title{
POSSIBLE HYBRIDIZATION BETWEEN BLUE JAYS AND STELLER'S JAYS
}

\section{GERRY WILDE, 276 Collinge Road, Hinton, Alberta. T7V 1L3}

Steller's Jays and Blue Jays in the Hinton area are at or beyond the limits of their respective ranges. However, in the past two years both have become fairly common visitors at my backyard bird feeder. Groups of jays are uncommon here because of their low numbers, particularly Steller's Jays.

In the spring of 1992, I was surprised to notice that a Blue Jay and a Steller's Jay were sharing the feeder. Usually Steller's Jays and Blue Jays show considerable aggression, particularly at the feeders, with the Steller's Jay being the dominant bird. I forgot about this until early in the first week of August when I again noticed Blue Jays and a Steller's Jay sharing the feeder. Upon closer examination I noted that there was one Steller's Jay and six Blue Jays of which five appeared to be young.

While observing these birds and their behaviour around the feeder I became convinced that I was watching a family of which a normal Blue Jay was the female, the Steller's Jay was the male and the young were hybrids. The young, which were easily recognized by their short tails, were in appearance very much like Blue Jays, except that they were very dark in colour. This darkness was apparent throughout the entire bird, with the blue areas being dark blue and the black areas wider and very black. The Blue Jay was a lightcoloured bird, which is typical for this area. It would call the young and assist them with their feeding. The Steller's Jay, although close by and obviously part of the group, did not appear to feed the young. This bird seemed to be a typical Steller's Jay, with normal coloration except for a small round white spot above the eye. I observed their family-like activities for approximately 10 days and after this period of time they gradually became less and less of a family unit. As of August 21 they still regularly visited the feeders, although they did not arrive as a family unit, but as individual birds.

The calls of the three types of birds appeared to be different with the Blue Jay and the Steller's Jay uttering normal calls. The young birds made a variety of calls, which did not resemble either of the two species' calls. These calls may or may not be typical of young Blue Jays, because they are not a common nester in this area, and I am not familiar with the call of young Blue Jays.

A quick review of the available literature presented no recognition of hybridization between these two species, although a colleague of mine indicated that hybridization was suspected between these two species in the United States. An interesting note is that the Hinton area is the most likely area in Canada of range overlap between these two species and that hybridization in other areas is most unlikely. 